\section{THE UNIVERSITY OF LONDON.}

$\mathrm{A}^{\mathrm{T}}$

T last, after six-and-thirty years of discussion, after the formulation of some twenty different schemes of reform and the report of two previous Royal Commissions, the Statutes and Regulations of the reconstituted University of London have been framed by the Commissioners appointed under the Act of 1898 , and the new University is created. The institution thus established is in its way unique ; there is nothing else exactly like it in the world, and it is therefore impossible to predict with any confidence what will be the extent or the nature of the influence it will exert on the progress of education either in the United Kingdom or in the restricted area over which its newly-created functions will be specially exercised. The old Examining Board will continue to exist almost as heretofore, and the famous system of examinations, which has undoubtedly been in its day potent for good, will be continued under safeguards and conditions but slightly altered. But in addition there is to be a new and distinct system administered by the same supreme authority, the Senate, which has hitherto directed the examinational machine.

Under this system students who pursue certain definite courses of instruction in recognised institutions or under recognised teachers will be admitted to degrees after passing certain examinations in which their own teachers will directly or indirectly take part. The institutions and teachers so recognised are situated within a radius of thirty miles from the central office of the University.

The purposes of the new University of London are declared by the Commissioners to be threefold: (I) "to hold forth to all classes and denominations, both in the United Kingdom and elsewhere, without any distinction whatsoever, an encouragement for pursuing a regular and liberal course of education"; (2) "to promote research and the advancement of science and learning," and (3) "to organise, improve and extend higher education within the appointed radius." Broadly, it may be said that of these three purposes the first has been more or less completely fulfilled by the previously existent system of examining all comers in subjects selected according to a definite scheme in orderly succession, from matriculation to the final examination for a degree. Without doubt the existence of this scheme, whatever drawbacks there may be to a pure system of examination which does not stop to enquire how the knowledge of the candidate has been gained, nor to ask too curiously as to its reality, has done great service to large numbers of industrious, intelligent and deserving students. Times, however, durming the last quarter of a century, have changed considerably in respect to the opportunities of higher instruction, and while the greater part of the United Kingdom has been divided into academic provinces, each with its own university and their affiliated colleges, London and the South have remained without many of the advantages which such institutions provide. London, however, possesses all the materials which are required for the equipment of a great university. The metropolis is the home of the great learned societies; it is also the central depository of the chief treasures of science, art, antiquities and industry in the national museums, and without disrespect to the many distinguished men connected with other parts of the kingdom, it is inevitable that a certain concentration of intellectual eminence should result from the attractions offered by the greatest city of the world. The third purpose of the new university will therefore surely be inseparably connected with (2) "the advancement of science and learning."

Under the new Statutes the University will consist of the Chancellor, the existing Fellows, for their respective lives, the Senate, the Graduates and the Students. It is enacted that the Chancellor of the old University shall continue to be Chancellor. The University will thus retain the advantage of Lord Kimberley's long experience as a member of the Senate. All else, however, will be changed. The existing Fellows are to retain their fellowships for life, but will cease as such to be members of the Senate, and probably many of them will drop out. The new Senate will be composed of the Chancellor, the Chairman of Convocation, and fifty-four persons who may or may not be graduates of the University. Of the fifty-four senators, sixteen will be elected by Convocation (chiefly graduates of the University), and sixteen by the Faculties (composed of teachers of the University). Of the remaining twentytwo, four are to be appointed by the Crown, and eighteen by various institutions, including six by the Inns of Court and the Incorporated Law Society. After the first two years the term of office of each senator will be four years. The Vice-Chancellor will be elected annually by the Senate from among its own members.

The work of administration will be accomplished chiefly through the medium of three standing committees of the Senate-namely, the Academic Council, the Council for External Students, and the Board to Promote the Extension of University Teaching. Concerning the last, it may be said, with considerable confidence, though not, of course, without fear of contradiction, that, however good its intentions, it cannot afford much assistance in the development of serious university work. The chief business of the University will be done by the two councils.

The Academic Council will consist of the Chancellor, the Vice-Chancellor, the Chairman of Convocation, the sixteen members of the Senate appointed by the Faculties, and an additional member or members to make up the number to twenty. Four-fifths of this council, therefore, consist of teachers. Their duties are advisory, and will relate to all that appertains to the Schools of the University, the appointment of Teachers, the organisation and regulation of the teaching, and generally to all matters which relate to the Internal Students-that is, to those students who have matriculated and are pursuing a course of study in a School or under Teachers of the University. The functions of the Academic Council are, therefore, the most important exercised on the part of the new University, and upon the care and judgment with which they are discharged will hang all the future development and usefulness of the University.

The Council for External Students is to consist of twenty-eight members of the Senate, whereof sixteen are the nominees of Convocation. The duty of this body is to watch over the interests of the External Students, who are defined as all matriculated students who are not Internal Students. Among the duties assigned to both these councils the difficult task is appointed of equalising, as far as possible, the standards of knowledge and attainments prescribed for the degrees conferred upon Internal and External Students respectively. But the Academic Council has nothing to do with External Students, and the other council has nothing to do with Internal Students; and unless provision is made by the new Senate for frequent conferences between the two councils, it is difficult to see how this equalisation is to be effected, for a mere inspection of syllabuses or of the questions set in examination papers would be, as every teacher or examiner could point out, a most delusive and inadequate test of equality. It is to be hoped that the Senate will bear in mind the importance of bringing these two councils into frequent contact, and that they will not be unduly influenced by fanatical adherents, if there be any, of the pure system of examination with its detailed limited syllabus, and its superstitious reverence for marks. Every encourageNO. I 586 , vOL. 6I] 
ment should be given to External Students to become Internal, and if in time the University acquires the means and the power to administer its own funds, the External Student may become an extinct species, so far as the science faculties are concerned. Then shall chemical analysis no longer be taught by post, and "correspondence" colleges fatten only on the ingenuous arts.

One or two points deserve to be noticed in connection with the examinations or qualifications for degrees. One novelty is the proposal to hold "separate matriculation examinations for different classes of students, having regard to the courses of study which the students propose to follow." This power will doubtless be exercised by the Senate with great deliberation. A loose interpretation of this provision might lead to consequences which would be disastrous for the future dignity and reputation of the University. It is easy to recognise here the influence of the "practical" man who is anxious to get rid of the incubus of the classical languages.

This is not the place to enter upon the discussion of that question, but coupling this suggestion of relaxation with the provision relating to the Bachelor of Science degree, it is easy enough to smell danger. For the degree of B.Sc., the Senate may accept in place of the whole or part of the final examination, the results of the study or research of any candidate who, in the opinion of the Senate, has thereby made a distinct contribution to the advancement of learning or science in any of the subjects in which that degree is conferred. Whatever may be the fate of Latin under the new arrangements, it is to be hoped that more care than ever will be taken to insist upon a real and practical conmmand by all candidates at matriculation of the orthography and syntax, if not the etymology, of their own language.

Another important statute gives power to the Senate to make arrangements to hold any intermediate examination or part thereof for the students of any School of the University jointly with the governing body of such School. In all such cases the examination would be conducted by the professor of the subject jointly with an external examiner appointed or recognised by the University. This recognition of college examinations was recommended by both the previous Royal Commissions.

The "Regulations" made by the Commissioners form a separate issue. They contain schedules of the Boards of Studies, of the recognised Teachers, of the provisionally recognised Teachers, and of the members of the Faculties, also details relating to the B.Sc. degree by research. It remains to be seen what will be the effect of requiring a student to submit to the Senate, before he begins his work, a statement of the nature of the research upon which he proposes to enter, and having started the research to carry it on for a period of not less than two years. Those who have a practical acquaintance with the prosecution of research, and the unexpected turns which inquiry often takes, will see some difficulties in these requirements; but it is, perhaps, worth while to make the attempt to develop a scheme by which successful work of this kind may receive academic distinction.

The business of the new University, like that of the old which it supersedes, still relates wholly to curricula, to studies, to examinations and degrees. The real value of a university in helping to form character and building up the intellectual and moral constitution of the man has no place, and could have no place, in the work of a Royal Commission. Nevertheless, the association of a number of institutions, individual and separate, though geographically near together, in a common interest and united effort cannot but have an effect in quickening the collegiate life of each, in promoting the mutual interest of teacher and student, in stimulating research, and in fostering schools of thought. Such ends the new University must keep clearly in view. The Senate must see to it that amid the clamour of contending interests, which for a few years can hardly be expected to be satisfied and silenced, the claims of true education shall not be forgotten.

W. A. T.

\section{DIFFICULTIES OF THE CALENDAR.}

\section{THE DATE OF EASTER.}

SOME interest has been excited by the fact that Easter appears to fall this year on a date not in accordance with the rule in the Prayer-Book; and a question was even asked about it in the House of Commons on Thursday last. The Attorney-General, of course, explained that the full moon of the Prayer-Book is not the real full moon, but the fourteenth day of the moon according to certain rules, confessedly not very simple or generally: "understanded of the people." The same difficulty was stated on the last occasion (in 1846) when this calendar or ecclesiastical full moon fell on a different day at Greenwich from that of the real full moon. But it may serve as an object-lesson on the futility of attempting to regulate Easter by the real moon, which would often produce the consequence of making it fall on a different day (that is, as it must be on a Sunday, a different week) at places some of which would be not far apart.

On the present occasion the absolute time of the full moon, which follows the vernal equinox, corresponds by Greenwich time to 2 minutes past I o'clock on the morning of April 15. All over Europe its time will be on the morning of that day: at Paris, at Ih. IIm.; at Berlin, at Ih. $56 \mathrm{~m}$. ; at Rome, at Ih. $52 \mathrm{~m}$. ; even so far west as Lisbon, at oh. $25 \mathrm{~m}$. (25 minutes past midnight on April 14), and therefore by civil time reckoning as April I 5. But on the west coast of Africa the local time of full moon will be before midnight on April I4; and in America, of course, still more so, its time at New York being 6 minutes before 8 o'clock on the evening of that day. The ecclesiastical full moon (artificially formed and tabulated) will be April I4, so that the Sunday following, i.e. the next day, April $\mathrm{I} 5$, will be Easter Day.

\section{The Russian Calendar.}

It is well known that the question has again been recently discussed of assimilating the Russian calendar with that of the rest of Europe ; but after consideration the Russian Government again decided against adopting the Gregorian reformation of the Julian calendar, according to which a leap-year is dropped in the last year of three centuries out of every four, the exception being those of which the century-number is divisible by four without rentainder. The Russian non-adoption of this is the cause that their calendar is several days behind ours, and has this year become one day more so than heretofore in consequence of their having a 29th of February in 1900, which those who follow the Gregorian reckoning have not. But they now propose to invite other nations to join them in adopting a rule for the calendar which will make it more accurate than the reckoning in question. Prof. Glazenap explained this at a meeting of the Russian Astronomical Society ; and, as it consists in dropping a leap-year at regular intervals instead of having an exception of an exception, which (as Sir John Herschel pointed out) needs, to be quite accurate, an exception again, we have no hesitation, on our part, in expressing approval of it. Prof. Newcomb, it may be remembered, in his "Popular Astronomy," suggested that there was no sufficient reason for abandoning the Julian reckoning, on the ground that it

NO. I 586, VOL. 6I] 